\title{
İyi'nin Kuruculuğu ile Değer'in Rehberliği Arasında Ahlak
}

\author{
Emrullah Kulıç \\ Dr., MEB, Çubuk Şehit Ömer Takdemir AİHL Fen ve Sosyal Bilimler Proje Okulu Müdürü \\ Dr., Ministry of National Education, Principal of Şehit Ömer Takdemir AiHL Science and Social Scien- \\ ces Project High School \\ Ankara /Turkey \\ ekilic0676@gmail.com \\ ORCID: 0000-0003-0221-0944
}

\begin{abstract}
The "Good" related to the ethical life is determined by the constitutive and prescriptive reason/will in the traditional life. The logo-centric good includes predetermined rules and systems. This kind of understanding can be read as a reflection of the traditional world and Western existence (presence) metaphysics. The good that we refer to as "value" in modern times, instead of following determinations and goals of a static center, aims to guide individuals with respect to the moral life. Thus, in the pre-modern traditional world, we can say that the moral system, which includes political determinations, was formed through theoretical production and aimed the good, which reflects the pre-determined set of rules and order. In the modern period, with the abandonment of teleological understanding of the universe, the good has left its place to the value. This resembles the foundation for the transition to the value that is human good by breaking away from the metaphysically determined ethical good in the sense of certain and unchangeable truth. Thus, the field of morality is has ceased to be a theological or metaphysical measure and subject outside of us, has turned into the field of contingency determined by human beings' own experience and evaluations of transcendence.

In this paper, values especially as in Heidegger's thought will be examined as the dimension of Dasein's own world and temporality. In this framework, values are based on ontological truth which represents the meaning of being instead of ontic truth. With this new situation, meaning and the good are sought inside of the "human being" or "this world" instead of "Being". Values are determined as functional good as a result of existential investigations instead of objective categorical investigations. Through this determination, values can be read as a deconstruction of the good. Thus, Heidegger offers distinctive existence and value. For Heidegger who aims to open the closedness of the being, truth is not an ultimate end or a decision, but an activity or haunt. The new truth that created by human's own evaluations, inclinations, concerns, and value with existence are discovered phenomenologically. With this situation, which can be read as Dasein's
\end{abstract}

İntihal Taraması/Plagiarism Detection: Bu makale intihal taramasından geçirildi/This paper was checked for plagiarism Etik Beyan/Ethical Statement: Bu çalışmanın hazırlanma sürecinde bilimsel ve etik ilkelere uyulduğu ve yararlanılan tüm çalışmaların kaynakçada belirtildiği beyan olunur/It is declared that scientific and ethical principles have been followed while carrying out and writing this study and that all the sources used have been properly cited (Emrullah Kilıç).

Geliş/Received: 28 Aralık/December 2020|Kabul/Accepted: 11 Şubat/Fabruary 2021|Yayın/Published: 20 Mart/March 2021 Atıf/Cite as: Emrullah Kılıç, “Iyi'nin Kuruculuğu ile Değer'in Rehberliği Arasında Ahlak = Ethics Between the Foundress of the Good and the Guidance of Value", Eskiyeni 43 (Mart/March 2021), 167-182. https://doi.org/10.37697/eskiyeni.848728 CC BY-NC 4.0 This paper is licensed under a Creative Commons Attribution-NonCommercial License 
expansion, the agent is guided on how to approach things in order to make themselves visible. Heidegger by this new foundation phenomenologically appropriates ancient understanding of truth instead of neglecting it. Thus, the individual's discovery of values turns into his/her heads towards Dasein's call and his/her interest over existing ones, instead of abstract metaphysical or theological truths.

For Heidegger, ethics is not something that is added later to a prefound theoretical subject. This situation doesn't reflect Dasein's authentic existence. Because, for him, the character of the self is not an object of selfdom that is imposed and unchanged. Selfdom can be realized by breaking free from impositions and opening the closure and re-founding the world through phenomenal discovery. Hence, he aims to take a new position toward life and produce new values. The value that represents Dasein's one-time existence (existenz) and also truth, grounds on the practical relationship that things get involved to reveal themselves their everyday encounter with the world rather than the set of rules imposed by certain structure of understanding. The value that reflects emergence of being through human experience, includes existential determinations that are based on a concrete individual rather than an abstract humanity and separate the human from everything as distinct from the good. By this means, the value in Heidegger can be read as a dynamic way of life that can be described as "letting-be".

In our paper, we subjected Heidegger's understanding of morality to a new reading, as a value that offers new discoveries to the individual and aims to guide him/her, - unlike the traditional good based on the metaphysics of existence - distinctly from traditional good based on Western's existence metaphysics. It is seen that the studies that separate good and value are insufficient in our country. Considering this situation, we hope that our study on Heidegger will contribute to the subject by bringing a new perspective in terms of the maturity that the value issue needs.

\section{Keywords}

Philosophy, Ethic, Good, Value, Heidegger, Deconstruction

\section{Öz}

\section{İyi'nin Kuruculuğu ile Değer'in Rehberliği Arasında Ahlak}

Ahlaki hayata dair “iyi”, geleneksel dünyada kurucu ve kural koyucu akıl/irade tarafindan belirlenir. Logos merkezli bu iyi, önceden belirlenen kurallar bütünü ve düzenini içerir. Söz konusu anlayış geleneksel dünyanın ve özellikle Batı varlık (mevcudiyet) metafiziğinin bir yansıması olarak okunabilir. "Değer" olarak ifade ettiğimiz modern dönemdeki iyi ise sabit bir merkezin belirlenimleri ve onun hedeflenen amaçlarının peşinden gitmek yerine bireylere ahlaki yaşam konusunda rehberlik etmeyi amaçlar. Nitekim modern öncesi geleneksel dünyada siyasi belirlenimler içeren ahlaki sistemin, teorik üretim yoluyla oluşup önceden belirlenen kurallar bütününü ve düzenini yansıtan iyiyi amaçladığını söyleyebiliriz. Modern dönemde teleolojik evren anlayışının da terk edilmesiyle birlikte, iyi yerini değer anlayışına bırakmıştır. Bu durum, kesin ve değişmez hakikat anlamındaki metafizik belirlenimli ahlaki iyiden koparak insani iyi olan değere geçişe zemin hazırlamayı temsil eder. Böylelikle ahlak alanı da bizim dışımızdaki teolojik ya da metafiziksel bir ölçü ve konu olmaktan çııı, insanın kendi aşkınlık tecrübe ve değerlendirmelerinin belirleyici olduğu olumsallık alanına dönüşmüştür.

Çalışmamızda özellikle Heidegger düşüncesinde var olan şekliyle değerler, Dasein'ın kendi dünyasında ve zamansallığında yapılan açılımının uzanımı olarak ele alınacaktır. Söz konusu anlamda değerler, ontik bir hakikat yerine, var-olmanın anlamının ne olduğunu temsil eden ontolojik hakikat üzerine temellenir. Yeni durumla, anlam ve iyi "Varlık" yerine "insanda" ve "bu-dünyada" aranır. Değerler, nesnel kategorik sorgulamalar yerine varoluşsal sorgulamalarla fonksiyonel iyi ola- 
rak belirlenir. Söz konusu belirlenimle değerler, iyinin tam bir dekonstrüksiyonu olarak da okunabilir. Nitekim Heidegger ayırt edici bir varoluş ve değer teklif eder. Varlığın kapalılığının açılmasını amaçlayan Heidegger'e göre hakikat bir son veya nihai bir karar değil bir aktivite ve uğraktır. İnsanın kendi değerlendirmeleri, yönelimleri ve kaygıları tarafından oluşturulan yeni hakikat ve değer ile varoluş, fenomonolojik olarak keşfedilir. Dasein'ın açılımı olarak okunabilecek bu durumla özneye, şeylerin kendilerini açığa çıkarmasını sağlamak için onlara nasıl yaklaşacağı konusunda rehberlik edilir. Heidegger yeni temellendirme ile kadim hakikat fikrini yok saymak yerine onu fenomenolojik olarak temellük eder. Böylece bireyin değerleri keşfetmesi, soyut metafiziksel veya teolojik hakikatler yerine var olanlar üzerinden Dasein'ın çağrısına yönelmesi ve ona ilgisine dönüşür.

Heidegger'e göre etik önceden kurulan teorik bir özne üzerine ilave edilen bir şey değildir. Bu durum Dasein'ın sahih varoluşunu yansıtamaz. Çünkü ona göre kendiliğin karakteri sürekli dayatılan, değişmeksizin var olan kendilik-nesnesi değildir. Kendilik, dayatmalardan sıyrılıp kapalılığı açmakla ve dünyayı fenomenal keşifle yeniden kurmakla gerçekleşebilir. Böylece o, yaşam karşısında yeni bir pozisyon alma ve yeni değerler üretilmesini amaçlar. Dasein'nın bir defalık varoluşunu (existenz) ve hakikatini temsil eden değer, belirli kavrayış yapısının dayattığı kurallar yerine dünyayla her günkü karşılaşmasında şeylerin kendilerini açığa çıkarmak üzere girdiği pratik ilişkiyi esas alır. Varlığın insani deneyimle açı̆̆a çıkmasını yansıtan değer, iyiden farklı olarak soyut bir insanlık yerine somut bir ferdi esas alan ve insanı haricindeki her şeyden ayıran varoluşsal belirlenimleri içerir. Söz konusu anlamda Heidegger'de değer, var olanı "oluruna bırakma” olarak nitelendirilebilecek dinamik bir yaşam biçimi olarak okunabilir.

Çalışmamızda Heidegger'in ahlak anlayışını -mevcudiyet metafiziği üzerine kurulu geleneksel iyiden farklı olarak- kişiye yeni keşifler sunan ve daha çok ona rehberlik etmeyi amaçlayan değer diye niteleyerek yeni bir okumaya tabi tuttuk. Ülkemizde de iyi ve değeri ayıran çalışmaların yetersizliğini göz önünde bulundurduğumuzda değer meselenin ihtiyaç duyduğu olgunluğa kavuşması bakımından Heidegger üzerine yaptığımız bu çalışmanın konuya yeni bir bakış açısı getirerek katkı sağlamasını umuyoruz.

\section{Anahtar Kelimeler}

Felsefe, Ahlak, İyi, Değer, Heidegger, Yapısökümü

\section{Giriş}

Herhangi bir sistemin içerisinde düşünmek, belirli bir referans çerçevesinde ve o sistemin vasıtalarıyla akıl yürütmek anlamına gelir. Bu durumun ahlak felsefesine dair temellendirmeler için de geçerli olduğunu söyleyebiliriz. Nitekim modern öncesi geleneksel dünyada siyasal belirlenimler içeren ahlaki sistemin logos merkezli kurucu unsurlarının, teorik üretim yoluyla oluşup önceden belirlenen kurallar bütünü ve düzenini içeren “iyi”yi amaçladığına tanık oluruz. Modern dönemde ise, teleolojik evren anlayışının da terk edilmesiyle birlikte, ulaşılmak istenen amaca göre karakterize edilen iyinin yerini, kendi amaçlarını tayin etmeye muktedir atomist-insan tanımıyla şekillenen yeni "değer" anlayışının aldığını söyleyebiliriz. ${ }^{1}$ Başka bir ifade ile söyleyecek olursak modern öncesi dünyada ahlaki temellendirmeler Varlık alanından doğmakta ve daha çok ezeliebedi hakikat fikri üzerine tek biçimli olarak yapılmaktaydı. Fakat kesin, değişmez ve

1 Derda Küçükalp, "Erdem Etiği”, Felsefe Ansiklopedisi, ed. Ahmet Cevizci (Ankara: Ebabil Yayınları, 2007), 5/628-629. 
ebedi olarak kabul edilen ontolojik hakikat anlayışı, modern dönemle birlikte terk edilerek Varlığın asli hakikati yerine, insanın etkinliğine güvenerek kendi gerçekliği ve hakikatinin yine kendisi tarafından belirlenmesi ile epistemolojik alana taşınmıştır. Söz konusu anlamdaki değişim metafizik belirlenimli 'ahlaki iyi'den koparak 'insani iyi' olan değere geçişe zemin hazırlamış, böylelikle ahlak alanı da bizim dışımızdaki teolojik ya da metafiziksel bir ölçü ve konu olmaktan çıkıp, insanın kendi aşkınlık tecrübe ve değerlendirmelerinin belirleyici olduğu olumsallık alanına dönüşmüştür. ${ }^{2}$ Nitekim geleneksel iyinin yerini süjenin yönelimi ve bağlllı̆̆ında ortaya çıan ve yeni iyi olan değer kavramına bırakması ${ }^{3}$ düşünce modunda meydana gelen büyük değişimlere paralel olarak "kendi başına var olan" iyinin kültürlerin farklılaşması karşısında gücünü yitirmesi ve yeni durumları karşılamada yeterince etkili olamamasının sonucu olarak da okunabilir. ${ }^{4}$ Zaten söz konusu anlamda 18. yüzyıldan itibaren monist yaklaşımların ekseninde oluşan metafizik ve teolojik iyiden farklı olarak değerler alanın daha çok kişisel duygu, tavır ve gerçeklik yorumlarından kaynaklanan, ilgi ve yönelimlerin nesnesi olan öznel durumları kapsayacak ${ }^{5}$ biçimde yeniden yapılandırılmaya başladığını da söyleyebiliriz.

Görüldüğü gibi ahlaki iyi, daha çok teorik kesin bilgi ve teolojik tayinler üzerinden tezahür eder ve tüm zamanlar için neyin iyi neyin kötü olduğunun belirlenmesini içerir. Söz konusu anlamda iyi, insanın zaman ve mekânla olan değişkenlik ilişkisinden ziyade kurucu ve kural koyucu akıl/irade tarafindan atanan hususları seslendirir. Bu çerçevede ahlaki eylemin hedefleri ve sonuçları daha eylem başlamadan öngörüldüğü için araçların seçiminde de herhangi bir bağlamsallık aranmaz. Fakat modern dönemde özellikle 19. yüzylldan itibaren iyi, hazır kurallara itaat sorunundan çok öte bir duruma işaret etmiştir. Bu çerçevede ahlaki akıl yürütme, verili olanı tespit ya da eksiksiz taklit etme olanağı sunmak yerine bulunduğu ortamda neyin ahlaken iyi ve kötü olduğunu keşfetmeye yönelmiştir. Başka bir ifadeyle ahlaki alanda akıl, mevcut ortamın ve şartların ahlaken talep ettiği şeyi görmede özneye yol göstermeyi amaçlamıştı. ${ }^{6}$ Çalısmamız öncelikle logos merkezli düşünme biçiminin sonucu olarak tek anlamlllk ekseninde kurucu iradenin kabulleriyle serimlenen iyinin temel niteliklerini ele alacak, akabinde iyinin yapısökümüne tabi tutulmasıyla oluşan ve amaçlardan çok anlamın ortaya konulduğu değerlerin ahlaki hayata verdiği ufku özellikle Heidegger (1917-1976) düşüncesi üzerinden inceleyecektir. Bu hususun anlaşılmasının ahlaki hayatın yeni durumlardaki tezahürüne ışı tutacağı umulur.

\section{Logos Merkezli Düşünme ve İyi'nin Kuruculuğu}

Logos merkezli düşünme biçimi insanı akıl sahibi canlı olarak yorumlayarak onun varlığı ve özünün belirlenişini aynı zamanda bir ihsan olarak kabul

2 Emrullah Kılıç, Metafiziksel Iyi'den Değer'e: Ahlakın Yolculuğu (Ankara: Ankara Üniversitesi, Sosyal Bilimler Enstitüsü, Doktora Tezi, 2020), 16-17.

3 Hans Joas, The Genesis of Value as Genealogy of Morality, çev. Gregory Moore (Chicago: The University of Chicago Press, 2000), s.20.

4 Celal Türer, Ahlaktan Felsefeye Felsefeden Ahlaka, (istanbul: Dergâh Yayınları, 2017), 67-68.

5 Ralph Barton Perry, General Theory of Value (Cambridge: Harvard University Press, 1950), 115.

6 Burhanettin Tatar, "Ahlakın Kaynağı Sorunu”, Ahlak Felsefesi Yazıları, ed. Lokman Çilingir (Ankara: Elis Yayınları, 2015), 21. 
eder. ${ }^{7}$ Var olana ilişkin söz konusu kavrama ve açıklama düzeninde ahlaki alandaki kurucu ve düzenleyici niteliğin Arap, Yunan ve diğer Akdeniz kültürleri üzerinde (yazının asırlarca bilinir olmasına rağmen) kalıplaşmış düşünme ve anlatım biçimiyle etkisini sürdürdügünü söyleyebiliriz. ${ }^{8}$ Nitekim bu geleneğin oluşumunda özellikle Platoncu logos merkezli yapının kurucu etkilerini görebiliriz. Platon'un (M.Ö. 427-M.Ö. 347) yazıya karşı çıkmasının sebebi taklit ve tekrar üzerine kurulu kültürde insanlığın hafıza kaybına uğrama endişesi sebebiyledir. Ayrıca Platon'a göre konuşma metne dökülünce dolaşıma çıkar ve ehli olmayanlar tarafından bağlamından kopartılarak yapısöküme uğratılabilir. ${ }^{9}$ Bu nedenle Platon sözün (parole), yani logos'un kaynağını ve oradan mülhem gücünü "babalık" konumuna has kılar. Kurucu "baba" figürü aynı zamanda "iyi” (agathon) figürüdür. ${ }^{10}$ Platoncu mevcudiyet (presence) metafiziğinde logos karşısında yazı değersizleştirilir. Phaidros Diyaloğu'nda; “Tanrı-kral Thamus, logos'un babası; yazı ise babanın yokluğunda kendi kendini yok etmeye yazgilı bir oğul" gibi sunulur. ${ }^{11}$

Hatırlanacağı üzere geleneksel dünyada ahlaki kararlar, yaratıcı açılımlar yerine daha çok kurucu bir normatif teoriye dayandırılarak verilir. Söz gelimi "metafiziksel iyi”nin kurduğu düzeni otorite üzerinden serimleyerek sürdürdüğünü söyleyebiliriz. Bu minvalde ahlaki eylemlerin nasıl olması gerektiğini ve yönünü önceden tayin eden daha çok logos-merkezciliğin bir sonucu olarak nitelendirilebilecek bu yaklaşımda aşkın bir kaynağa bağlantı vardır. Bu referans ahlaki eylemlerin kurucu unsuru olan "otorite" (authority) bağlantısıdır. Sabit ve otoriter bir merkezi varsaymasından dolayı da daha çok teolojik olmak durumundadır. Hiyerarşik ve kutupsal karşıtlıklar zemininde kurulan bu yapıda "kim olduğumuz?" sorusunun cevabı da sabit ve kalıcı tanımlamalar içerir. Söz konusu otoriter yapıda ahlaki eylemelerdeki öznellik de özsel ve sabit anlamlarla ilişkilidir. $^{12}$

Yukarıda ifade edilen hususlardan hareketle, metafiziksel düşünceden mülhem ahlak anlayışının "aynılık” ve "özdeşlik” üzerinden; modern dönemde öznellikle serimlenen değerlerin de "farkllık” ve "ötekilik” üzerinden temellendirilen ahlaki taleplerle oluştuğunu söyleyebiliriz. Metafiziksel düşünme geleneğinin temel karakteristiği, nesnel bir temellendirme için mutlak bir zemin ve her şeyin kontrol edildiği kurucu bir Arşimet noktası bulma gayretidir. Söz konusu Varlık anlayışından hareketle hakikatin temellendirildiği bu yapıda ahlaki hayat kurucu iradenin belirlenimlerine uygun biçimde tezahür etmiştir. Buna mukabil ahlaki hayata dair modern dönemdeki söz konusu durum, insanın kendi talepleriyle birlikte ötekinin kabulü doğrultusunda dünyayı yeniden anlamlandırma gayretiyle ilgilidir. Bu gayret ahlaki amaçların sürekli olarak revize edilmesinin yansıması olarak da okunabilir. Böylece ahlaki olan, özdeşlik çerçevesinde olması

\footnotetext{
Martin Heidegger, Varlk ve Zaman, çev. Kaan H. Ökten (istanbul: Agora Kitaplığı, 2011), 51.

8 Walter J. Ong, Sözlü ve Yazıl Kültür: Sözün Teknolojileşmesi, çev. Sema Postacioğlu Banon (ìstanbul: Metis Yayınlar1, 2010), 40-41.

9 Platon, Phaidros, çev. Furkan Akderin (ìstanbul: Say Yayınları, 2017), 95-96.

10 Jacques Derrida, Platon'un Eczanesi, çev. Zeynep Direk (istanbul: Pinhan Yayınları, 2014), 27-32.

11 Kasım Küçükalp, Batı Metafiziğinin Dekonstrüksiyonu: Heidegger ve Derrida (Bursa: Sentez Yayınları, 2008), 283.

12 Küçükalp, Batı Metafiziğinin Dekonstrüksiyonu: Heidegger ve Derrida, 276-277.
} 
gerekenin normu, baskısı ve yapısal donukluğu yerine, ihtiyaç ve taleplerin dinamikliği ile farkl11ıklar üzerinden inşa edilen yeni bir yol gösterici rehberlik alanına dönüşür. ${ }^{13}$ Söz konusu rehberlikte benlik, insanın inşa ettiği dünyayla ilişkili bir benliktir. Öznel eylemler ile gerçekleşen benlik kişinin tanım veya taklit yerine dünyayla kendine has benzersiz ilişkisini belirleme yeteneğinin ifşası olarak tezahür etmektedir. ${ }^{14}$ Dolayısılla değerin, teorik bir hakikat kavramını referans almaksızın, tıpkı bir sanat eseri gibi bireyin yaratıcl l̆ğı ile ona ufuk vererek oluştuğu ifade edilebilir. ${ }^{15}$

Toparlayacak olursak geleneksel dünyada, başka bir şeye ihtiyaç bırakmaksızın Varlğı̆n gölgesinde șekillenen teori ve pratik, modern dönemle birlikte Varlık ve değer ayırımı neticesinde yerini özneden nesneye gidişin yolu olan metoda bırakmıştır. Özellikle Descartes (1596-1650) ile birlikte modernliğin metodik dayatmaları kaçınılmaz olarak teori ile pratik arasında derin boşluklar oluşturmuştur. Arada kalan boşluk ve buradan neşet eden problemler Varlıksal veya metodik çözümlerle giderilememiş, sorunun çözümlenmesinde pratik ve anlam ön plana çıkmıştır. Nitekim bu durum hem düşünme hem de ahlaki hayat için yeni bir mod değişimini beraberinde getirmiştir.

Sözü edilen yeni tutum 17. yüzyıldan itibaren felsefe için güvenli bir liman aramanın sonucunda kesinlik kaygısıyla oluşan metot ve rasyonellik tartışmalarına bilim, hermenötik ve pratik ile cevap verilmesinin yansıması olarak okunabilir. ${ }^{16}$ Söz gelimi John Dewey (1859-1952), geleneksel anlayışta mükemmel varl lğı temsilen Varlıksal olarak temellendirilen insan davranışında karşılaşılan problemlere dikkat çekerek, insan davranışlarının yönü hakkında bilimsel önermelerin imkânını soruşturur. Çünkü ona göre değerlerin oluşumu için bilim ile değerler arasındaki boşluk doldurulmalıdır. ${ }^{17}$ Öyle ki söz konusu boşluğun öznenin lehine doldurulmasının neticesinde özellikle modernlik sonrasinda tümel yerine tikel, sabit yerine değişken olana itibar edilmiştir. Bu durum nihayetinde ahlaki iyinin yerini değere bırakması ile sonuçlanmıştır.

\section{2. İyi'nin Dekonstrüksiyonu ve Varoluş Kipi Olarak Değer}

Varlıkla ilişkili nesnel hakikatler ve şematik yapılar üzerine inşa edilen geleneksel “iyi”nin Dasein'ın çağrısı ile değişim ve farklılıklar üzerinden öznellikle inşa edilen “değer"e dönüşmesi, iyinin tam bir dekonstrüksiyonu olarak okunabilir. Nitekim değerler alanında Heidegger ayırt edici bir varoluş biçimi teklif eder: Değerler alanıyla mevcudiyet metafiziğinde ihsan olarak kabul edilen ve var olan açısından karanlıkta kalan Varlığın kapalılığının açılması amaçlanır. ${ }^{18}$ Nitekim Heidegger'e göre Dasein kendini “insana ve insanda" açar. ${ }^{19}$ Söz konusu durum, hakikatin bir son veya nihai bir karar oluşunu

13 Burhanettin Tatar, Din, İlim ve Sanatta Hermenötik (İstanbul: İsam Yayınlar1, 2014), 122-125.

14 Eugene Lawrence McCarney, The Idea of Freedom in the Philosophy of William James (Chicago: Loyola University Chicago, The Faculty of Graduate School, Yüksek Lisans Tezi, 1963), 76-77.

15 Michel Foucault, Özne ve İktidar, çev. Işık Ergüden - Osman Akınhay (İstanbul: Ayrıntı Yayınları, 2014), 23.

16 Celal Türer, “Modernliğin Yöntem Tiranlığı”. Eskiyeni / 17 (Haziran 2010), 5-10.

17 John Dewey, "Theory of Valuation”, International Encyclopedia of Unified Science, ed. Otto Neurath (Chicago: The University of Chicago, 1943), 2/4.

18 Heidegger, Varlk ve Zaman, 324-325.

19 Georg Steiner, Heidegger, çev. Süleyman Kalkan (Konya: Vadi Yayınları, 1996), 136. 
değil, bir aktivite ve uğrak olarak görülmesinin yansıması şeklinde okunabilir. ${ }^{20} \mathrm{Bu}$ çerçevede Varlık felsefesi karşısında Nietzsche'nin (1844-1900) “oluş” temelli “Dionysosçu” felsefesini, Heidegger'in ontik-ontolojik ayrımını ve Derrida'nın (1957-2004) "différance" kavramını refere alarak ortaya koymaya çalıştığı şeyi aynı bağlamda değerlendirmek mümkündür. Çünkü mezkûr yaklaşımlar Batı metafizik düşünce geleneğine ait mevcudiyet fikrinin uzanımı olarak Varlıkla ilişkili kurucu ilkeler ve sabitlikler üzerinden tezahür eden klasik yaklaşımın yapısöküme uğratılmasından başka bir şey değildir.

İyiden farklı olarak değerler, herhangi kurucu bir unsurun ya da otoritenin tahakkümü yerine kendilik formunun özümsenmesiyle tezahür eder. Değerler, soyut belirlenimlerle değil içinde oluştuğu somut gerçekler, imkânlar ve varoluş kipiyle ilişkili kabul edilir. ${ }^{21}$ Düşünce sisteminin değişimi sonucu geleneğin içinden konuşmak yerine süjenin neyi değerli bulduğunun öncelenmesi ile oluşan değerlerin ahlaki hayata dair pek çok değişikliği de beraberinde getirdiğini söyleyebiliriz. Artık ahlaki hayatın önceden vazedilen "erdemler tablosu" ile belirlenmesi mümkün değildir. Nitekim Nietzsche'ye göre "ahlaksal yargıların yanılsamaların temelden yakalamak"22 ve değeri gündelik yaşamın içerisinde arayarak yaşamla çelişmeyen değerlere yönelmek gerekmektedir. $^{23}$

Heidegger'e göre önceden belirlenen referanslarla kurulan, Dasein'ın dünyaiçinde-Varlığını görmezden gelen ve "göndermeli bütünlük" olarak ifade edilen ahlaki değerlendirmeler "Varlık kaybına" neden olmaktadır. Dolayısıyla değerler alanında iyi, kalıcı bir Var olan (das Seiende) ve nesnel hakikat olarak ele alınmak yerine, tarihin büyük problemleri ile birlikte Varoluş (das Sein) çağrısına göre değerlendirilir. ${ }^{24}$ Varlığı boş tahmin ve fikir yürütmelerden kurtarıp onun hakikati üzerine düşünmeyi esas alan bir ontoloji inşa etmeye çalş̧an Heidegger varoluşu sadece "hep-benimkilik" niteliğine uygun olarak Dasein'a tahsis eder. ${ }^{25}$ Dasein'ın kendi Varlığına yönelimi ile kurduğu bu hakiki ilişki hep kendi imkânı olarak vardır. Kendinden önceki insan ve Varlık anlayışından sapmayı yansitan söz konusu durumla insan yeni bir kategoriye tabi tutulur. Geleneksel var olanın neliği (essentia) yerine, kendi varlığından (existentia) hareket eden Heidegger'e göre insanın dünya ile ilişkisi ancak onun ilgi ve yönelimleri ile mümkün olmaktadır. ${ }^{26}$ Söz konusu durum insanın harici güçler yerine kendi tasarılarını oluşturmasının yolunu açar. Kendi tasarıları doğrultusunda kendi sorularını sorabilen ve bu doğrultuda nasıl davranması gerektiğine kendisi karar verebilen insan böylelikle sahici bir yaşama ulaşabilir. Sahici yaşamın motivasyonunu, geleneksel dönemde olduğu gibi iyi yaşam

20 Küçükalp, Batı Metafiziğinin Dekonstrüksiyonu: Heidegger ve Derrida, 240.

21 Veli Urhan, Michel Foucault ve Düşünce Sistemleri Tarihi (İstanbul: Say Yayınları, 2013), 358-359.

22 Friedrich Nietzsche, Putların Alacakaranlı̆̆ı, çev. İsmet Zeki Eyüboğlu (İstanbul: Say Yayınları, 2014), 57.

23 Friedrich Nietzsche, Güç İstenci, çev. Nilüfer Epçeli (İstanbul: Say Yayınları, 2014), 190.

24 Kenneth W. Stikkers, "Value as Ontological Difference”, Phenomenology of Values and Valuing, ed. James G. Hart - Lester Embree (Dordrecht: Kluwer, 1996), 139-147.

25 Martin Heidegger, Hümanizm Üzerine, çev. Yusuf Örnek (Ankara: Türkiye Felsefe Kurumu, 2013), 49.

26 Heidegger, Varlk ve Zaman, 44-45. 
için birlikçi bir düzen ya da modern dönemde olduğu gibi bilinçle kurulan (cogito) yerine insanın kaygıları ve varoluş sancıları oluşturur. Söz konusu kaygılarla yüzleşmek Heidegger'e göre gelecekteki yokluğu (ölüm) kabul etmekle mümkün olur ve bu da sahici yaşam tarzına atılan ilk adım olarak kabul edilir. Dasein'ın ontoloji olarak belirlenimi var olanın asli yorumuna işarettir ve bu yorum iyiye rehberlik edecek en önemli husustur. ${ }^{27}$ Heidegger'e göre insanın, kendine ve etkinliğine olan güven içerisinde bilginin otoriter kipi olan "kesinlik" ile aslında hesaplanamaz olan gerçekliği tarihsel akıl ile kurgulaması, Varlığın asli anlamının sınırlandırılması ve nihayetinde unutulmasına yol açmış ${ }^{28}$ "Varlığın hakikati sorusunu dahi gündemden düşürerek önünü tıkamıştır." ${ }^{29}$ Bu nedenle Varlık hakkındaki inceleme (ontik) yerine var-olmanın anlamının ne olduğu üzerine yapilan inceleme (ontolojik) yapan Heidegger, nesnel (existentiell) kategorik sorgulamalar yerine varoluşsal (existential) sorgulamalar yaparak üstü örtülmüş olanı açabilmeyi olanaklı kılmayı amaçlar. Heidegger'e göre Varlık, var olan gibi nesnel olarak tasarlanamaz. Yukarıda ifade edildiği gibi var olanı nesneleştirme çabasının bir tür egemenlik kurma teşebbüsü olduğuna işaret eden Heidegger, Batı düşüncesinin en büyük yanılgılarından biri olan bu ilişkiyi Varlığı var olana indirgemeksizin açılımlayarak aşmak ister. ${ }^{30}$ Söz konusu açılım insan varlığı üzerine değil "insan olma olanağı" üzerinedir. İște bu insan olma imkânı da bizzat insanın kendi değerlendirmeleri, yönelimleri ve kaygıları tarafından oluşturulur. Söz konusu insanileştirme öncelikle modern dönem öncesi ahlaki iyinin kendini kurarken koyduğu açılımların fark ettirilmesini esas alır. Akabinde logos merkezli Varlık anlayışının tahrip edilerek söz konusu anlayıştaki belirsiz soyutlamalar yerine fenomonolojik yöntemin ikame edilmesi aşamasına geçilir. Dolayısıyla Varlığın varoluş yapısının ortaya konulmasının, Dasein'ın kendi dünyasında ve zamansallığında yapılan bir açılım olduğunu söyleyebiliriz. ${ }^{31}$

Heidegger, aynı zamanda bir iktidar biçimi olarak gördüğü geleneksel kavramları ters yüz ederken söz gelimi Nietzsche'de olduğu gibi tarihin yadsınması yerine aktarılmış olanın dönüştürülmesini tercih eder. Geleneksel Batı metafiziğindeki hakikati "verilmiş doğruluk" olarak kabul etmek yerine "huzursuzluk kaynağı" olarak deneyimlediğimizi ifade ederek onu revize etmek ister. ${ }^{32}$ Söz konusu durum metafizik ve hakikate dair mevcut tarihi açıklamaları yıkmaktan ziyade var olanın varlığı olarak geçmişte bize konuşanı duyarak onunla konuşmaya ulaşmayı temsil eden durumu "içinde ikamet ederek" ele geçirmeyi yansıtır. ${ }^{33}$ Nitekim Varlık için yaptığını logos üzerinden de devam ettirir. İfade ya da yargı anlamında ifade olarak kullanılan logosu varlı̆̆ı örtmek yerine açık

27 Heidegger, Varlıve Zaman, 256-257.

28 Martin Heidegger, "Metaphysics as History of Being", The End of Philosophy", Translate: Joan Stambaugh (United States of America: University of Chicago Press, 2003), 20-21.

29 Martin Heidegger, Hümanizm Üzerine, 37.

30 Martin Heidegger, Metafizik Nedir? çev. Yusuf Örnek (Ankara: Türkiye Felsefe Kurumu, 2009), 45-47.

31 A. Kadir Çüçen, Heidegger'de Varlk ve Zaman (Bursa: Asa Yayınları, 2003), 41-43.

32 Martin Heidegger, Basic Questions of Philosophy, Translated: By Richard Rojcewicz and Andre Schuwer (Bloomington \& Indianapolis: Indiana University Press, 1994), 20.

33 Martin Heidegger, Nedir Bu Felsefe? çev. Ali Irgat (İstanbul: Afa Yayınları, 1995), 45. 
hale getirmeye matuf bir söylemin ifadesi olarak Legomenon anlamda kullanır. Dolay1sıyla söz konusu tanımlama ile Heidegger, logos merkezli tarih üstü iyi yerine Legomenonun ilişkiselliğinde açı̆̆a çıkan ${ }^{34}$ insani iyiyi benimser. Zaten Heidegger; dil, bilgi ve toplumun temeline ait araştırmalarındaki genel tutumunda olduğu gibi ahlakın da "sosyal pratikler ya da ben-imajını ebedileştirme yönünde apolojetik teşebbüs” olabileceğini göz ardi etmez. ${ }^{35}$

Tüm bu hususlardan hareketle Heidegger'e göre kendilik bilinci salt öznel bir sürece de işaret etmez. O, Descartes'ta olduğu gibi dünyayı öznenin bilinciyle kurmaz. Aksine kendilik bilinci, Varlığın zamanla kurduğu rabıta ile zamana açılımlanması neticesi oluşur. Çünkü ona göre ister "a priori" isterse "empirik" bir temellendirmeye tabi tutulsun ideal özne yoktur. Söz konusu durum Heidegger' in hakikat anlayışı ile de doğrudan ilgilidir. Ona göre bir şeyi, başka bir var olanın varlık zemininde aramak, dolayısıyla hakikati varsaymak zorunludur. Heidegger'de hakikat ve anlam zamansallıkta Dasein'la kurulan asli bir rabıta içinde aranır. ${ }^{36}$

Nitekim yeni durumla önceki metafiziksel yargılar ve ahistorik iyi anlayışı yerine pratikler ve dünyadaki nesnelerle günlük ilişkiler açısından Dasein, geleneksel anlayıştan farklı olarak yaşamın yeni bir analizine dönüşür. Heidegger bu anlamda daha önce Yunanca ruh (psyche) ve bilinç (consciousness) olarak adlandırdığı kavramlara daha sonra yaşam (life) anlamı verir. Dolayısıyla bir Varlık minvali olan Dasein'ın açımlanışı “dünyaiçinde-var olmanın" fenomenolojik keşfine ve yaşanmış varoluşun tam bir erişime açılmasına dayanır. ${ }^{37}$ Nitekim Heidegger'e göre fenomenoloji, şeylere, saklanmış olanı açığa çıkarmak için belli bir kavrayış yapısının dayatmaları neticesi nesnenin karşısında durmak zorunda kalan bir özne yerine, şeylerin kendilerini açığa çıkarmasını sağlamak için onlara nasıl yaklaşacağını gösteren bir bakış açısıdır. ${ }^{38}$

Önceden belirli kesinlikler yerine adeta yaşamın yaşamla açıklanmasını temsil eden söz konusu durum yukarıda da ifade edildiği gibi metafiziksel hakikat ve iyi fikrinden tam bir ayrışmayı temsil eder. Çünkü geleneksel anlamda logos ve aletheia ile ortaya konulan "formel” hakikat yeni açılımla "fenomenal” gösterimine kavuşmuş olur. Heidegger yeni temellendirme ile kadim hakikat fikrini yok saymak yerine onu fenomenolojik olarak temellük eder. Böylece keşif, soyut metafiziksel veya teolojik hakikatler yerine var olanlar üzerinden failin Dasein'ın çağrısına yönelmesi ve ona ilgisine dönüşür. Ona göre keşfedilen hakiki olandır. Dünyanın açımlanışı üzerine temellenen hakikat önceden tasarlanan amaçlar yerine "öylesine- bakışsal ilgilenme” ile gerçekleşir. Daha açık bir ifade ile hakikatin ve onun açılımı olan insani iyi ya da değer, zamanın çağrısına kulak verme neticesinde tasarımdan ziyade "kendiliğinden" açığa çıkan bir

34 Çüçen, Heidegger'de Varlıkve Zaman, 51.

35 Richard Rorty, Felsefe ve Doğanın Aynası, çev. Funda Günsoy Kaya (İstanbul: Paradigma Yayınları, 2006), 16.

36 Çüçen, Heidegger'de Varlıkve Zaman, 241-249.

37 Thomas Nenon, "Values, Reasons for Actions, and Reflexivity" Phenomenology of Values and Valuing, ed. James G. Hart-Lester Embree (Dordrecht: Kluwer, 1996), 28/131-134.

38 Patricia Altenbernd Johnson, Heidegger Üzerine, çev. Adnan Esenyel (Bursa: Sentez Yayınları, 2013), 30. 
oluşu seslendirir. ${ }^{39}$ Böylece onun "varlıkları" kendi hallerine bırakmasından, bir başka ifadeyle Heideggerci bir tevekkülden söz edebiliriz. ${ }^{40}$ Söz konusu durum her ne kadar motivasyonu farklı olsa da özellikle Adam Smith'in (1723-1790), herhangi bir Varlık veya yasadan ziyade bireylerin eylemlerinden neşet eden ve karşllıklı onama ile oluşan "kendiliğinden doğan" düzenini çağrıştııır. ${ }^{41}$ Fakat Heidegger'in düzeninin Smith'in düzeninden farklı olarak pragmatik ve faydacı olmayan bir oluşu seslendirdiğini söyleyebiliriz. Çünkü ona göre söz konusu kendiliğinden oluş, çıkar ilişkileri ve karşllıkl onamadan ziyade kendiliğinden açığa çıkan esrimeyi yansıtır. Ona göre bir temelden hareketle yenilenmeye ve canlandırmaya karşıllık yaratmak "bir kaynaktan çekmek" olarak ifade edilebilir. Bu nedenle varoluşun sahici gövdesi ile irtibatlanmadan kurulamaz. Bu irtibat, şairin çağrısıyla gerçekleşecek varoluş kipi ile kurulur. Söz konusu durum, kutsal tapınağın köklerinin bulunduğu, gizlenmişliğin sembolü koruyucu toprak ile açıklığın yeri olan göğün sahici biçimde gövdeye bürünmesini temsil eder. Ona göre ancak bu durumda hakikat tecelli edebilir. ${ }^{42}$

Nitekim Heidegger'e göre "Sanat hakikatin gerçekleşmesi ve oluşması demektir. Hakikat mevcut ve alş̧ldılk olandan okunmaz. Var-olanın aydınlanması ve açık olanın açılımı firlatılmılslığa ulaşan açıklğın tasarımlanmasıyla gerçekleşir. ${ }^{43}$ Çünkü ona göre hakikatin varlığında tıpkı sanat eserinde olduğu gibi gizlilik egemendir. Söz konusu anlamda "yeryüzü" kendini kapama ve gizlemenin adıdır. Fakat "dünya" ve "yeryüzü”, varlık açısından birbirinde farklı ama asla birbirlerinden ayrılmazlar. Çünkü dünya kendini yeryüzüne kurar, yeryüzü de dünyada yükselir. Dünya yeryüzüne yaslanır. ${ }^{44}$ Yeryüzüne aitlik ile dünyaiçinde varoluş arasındaki gerilim sanat eserinde tezahür eder. Eserdeki nesnelliği temsil eden yeryüzü, dünyayı açllıma götürür ve böylece yeryüzünün üretimi ile dünya kurulur. Söz gelimi tapınak taştan yapılmıştır fakat hakikati ulûhiyeti temsil eden bir dünyaya göndermede bulunur. ${ }^{45}$ Söz konusu durum tarihsel süreçlerde hakikatin saf biçimde bulunmayıp bağlam içerisinde gizlenmişliğini yansıtır. Nitekim Heidegger'e göre varoluşa dair değer üretmenin, yeryüzünden kopmadan dünya içinde, gizleme ile açığa çıkarma arasındaki gerilime rağmen sanatçı edasılyla hakikati tespit edebilme gayreti olduğunu ifade edebiliriz.

Heidegger'e göre bir yolculuk hâli olarak Varlığın zamanla birlikteliğinde ${ }^{46}$ ahlaki olan önceden teorik bir özne kurup daha sonra üzerine etik ilave etmek değildir. ${ }^{47} \mathrm{Bu}$ durum Dasein'ın sahih varoluşunu yansıtamaz. Kendiliğin karakteri sürekli dayatılan,

\footnotetext{
39 Çüçen, Heidegger'de Varlk ve Zaman, 232-233.

40 Allan Megill, Aşırılığın Peygamberleri, çev. Tuncay Birkan (Ankara: Ayraç Kitabevi, 2008), 308.

41 James Otteson, “Adam Smith's Marketplace of Morals”, Archiv für Geschichte der Philosophie 84/2 (2002), 190-211.

42 Steiner, Heidegger, 141-149.

43 Martin Heidegger, Sanat Eserinin Kökeni, çev. Fatih Tepebaşılı (Ankara: De Ki Basım Yayım, 2011), 68.

44 Martin Heidegger, Sanat Eserinin Kökeni, 43-48.

45 Martin Heidegger, Sanat Eserinin Kökeni, 108-110.

46 Kurtul Gülenç “Bilim, Düşünme ve Varlık: Heidegger'de Fenomenolojik Hermeneutik”, Cogito Üç Aylık Düşünce Dergisi 64 (2010), 287.

47 Çüçen, Heidegger'de Varlkve Zaman, 334.
} 
değişmeksizin var olan kendilik-nesnesi yerine, dayatmalardan sıyrılıp kapalılı̆̆ı açmayı ve öz anlamda kendini gizleyen yeryüzünün üretimi ile dünyayı kurmayı amaçlayan bir keşifle oluşur. ${ }^{48}$ Dolayısıyla keşifle açığa çıkanın, teorik öznenin bilinci tarafından kurulan iyi yerine, örtük biçimde bulunan hermenötik keşiflerle kendiliğinden oluşan değerlendirmelere ufuk verdiğini söyleyebiliriz. Çünkü değerler alanı, teoride önceden belirlenmiş (konumlanmış) bir alan olmadığı için belirleyici bir güçle de açıklanamaz. ${ }^{49}$ Heidegger'de daha çok anlamlılık üzerinden anlaşılan değerin aynı zamanda insanın yaşam karşısında bir pozisyon alma yeteneği olduğunu ifade edebiliriz. ${ }^{50}$

Yukarıda ayrıntılı bir şekilde açıklanan hususlara ilaveten Heidegger'in değer anlayışını anlamak için Herakleitos'un (M.Ö.535-M.Ö.475) kendini görmek isteyen yabancılara söylediği söz hakkındaki aktarımına müracaat etmek açıklayıcı olacaktır: Heidegger'in aktardığına göre Herakleitos'u merak edip görmek isteyen bir grup yabancı, düşünürü, hep alışılagelmiş sıradan yaşam biçimi dışında istisnai ve ender olan bir ortamda "tam derinlere dalmış düşünürken bulmayı" umarak ziyarete niyetlenirler. Aynı zamanda yaptıkları ziyaretten bir takım felsefi aforizma ve eğlenceli malzeme elde etmeyi beklemektedirler. Heidegger'e göre ziyaretçiler Herakleitos'un düşünmesinin etkisinde kalmaktan ziyade sadece filozofu görüp onu dinlediklerini başkalarına anlatabilmek için o anı "yaşamak” istemektedirler. Fakat Herakleitos'u ziyaret ettiklerinde onu düşünürken değil, fırının başında beklerken bulurlar ve tam bir hayal kırıklığı yaşarlar. Hiçbir özelliği olmayan bu fırının başında Herakleitos ekmek bile hazırlamamakta, sadece ssınmak için orada bulunarak hayatının tüm yoksulluğunu gözler önüne sermektedir. Okuyup düşünen bir filozof yerine üşüyen bir filozofla karşılaşan yabancılar hemen oradan ayrılmaya karar verirler. Durumu fark eden Herakleitos onları cesaretlendirip geri döndürmek için şu sözleri söyler: "Tanrılar burada da özlerini sürdürüyorlar." Heidegger'e göre bu söz, düşünürün orada eğleşmesine ve eylemesine yeni bir ışık tutmaktadır. Söz konusu öykünün önemi "düşünürün etrafındaki atmosferden çıkmasında ve o atmosfere işaret etmesinde" yatar. "Burada da", firında, bu alışılagelmiş yerde, her şeyin ve her halin, her eylemin ve düşünmenin tanıdık ve bildik, yani olağan olduğu yerde, "yani burada da", olağan olanın içinde de "Tanrılar özlerini sürdürüyorlar." Çünkü Herakleitos'a göre "insana göre (olağan) eğleşme, Tanrı'nın (olağan-üstü olanın) özünün gelişi için açık olandır.” Herakleitos’u ziyarete gelenler ve onların tutumları karşısında düşünürün, insanların eğleşmesi üzerine kafa yorması Heidegger'e göre değerin kendisidir. Çünkü değer üretmek, orada olan var olanı kendi varlığı içinde düşünme ve bulmayı (ziyaretçilerin önceden tasarladıkları hâliyle sadece Herakleitos'u düşündükleri biçimde görme arzusu) aşıp Varlığın, hakikat ve köklü biçimde düşünmenin ait olduğu ontolojik öze yaptığı çağrısı ile mümkün olur. Heidegger'e göre söz konusu çağrı Herakleitos’un “İnsanın karakteri, onun daimonudur." ifadesindeki ile aynı işaret ve imaya sahiptir. Çünkü ona göre bu ifade ile Herakleitos "bir yerde bulunmayı ve ikamet edilen açık alanı" kasteder. Çünkü

48 Çüçen, Heidegger'de Varlıkve Zaman, 342.

49 David Wiggins, Needs, Values, Truth (ABD: Oxford University Press, 1998), 88.

50 Nenon, “Values, Reasons for Actions, and Reflexivity”, 125. 
Heidegger'e göre bulunduğu yerin açıklı̆̆ı önceden belirlenim ve tasarımlardan ziyade "insanın özüne ait olanı ve böylece de oraya gelişinde onun yakınlığında bulunanın görünmesine izin verir, insanın eğleşmesi, insanın özünde ait olduğu şeyin gelişini içerir ve korur." Nitekim Herakleitos'a göre daimon Tanrıdır ve "İnsan, insan olduğu için Tanrı'nın yakınlığında ikamet eder." Söz konusu anlamda da Heidegger'e göre Varlıktan hareket ederek nasıl yaşanması gerektiğine dair önceden bir temellendirme ancak "asli/ahlaki iyi" olabilir. ${ }^{51}$ Fakat Heidegger'in Dasein'nın bir defalık varoluşunu (existenz) ve hakikatini düşünerek, belirli kavrayış yapısının dayattığı kurallar yerine dünyayla her günkü karşılaşmasında şeylerle girdiği pratik ilişki temelinde ve şeylerin kendilerini açığa çıkarmasını sağlayarak yaşamı anlamlandırmaya çalışmasını "değer" olarak ifade edebiliriz.

Toparlayacak olursak Heidegger' in Batı mevcudiyet metafiziğine yönelttiği Varlık sorusu ile hakikat, anlam ve logos sorunu olarak kaşımıza çıkmıştır. Geleneksel dönemin kurucu kavramlarının çoğunun etkisini yitirmesine neden olan bu anlayış, hakikat fikrinin yeni bir paradigma ekseninde inşasını da beraberinde getirerek Varlık alanı başta olmak üzere iyiye dair de pek çok hususun yeniden değerlendirilmesine neden olmuştur. ${ }^{52}$ Söz konusu yeni süreçte Batı metafiziği düşünce geleneğinde ortaya konulan logosmerkezci Varlık, hakikat ve ahlak anlayışları Heidegger ve Derrida gibi düşünürlerin dekonstrüksiyoncu yöntemleri ile önceden belirlenen kesinlikler yerine ilişkisellik, bağlamsallık ve zamansallığa vurgu yapılmak suretiyle yeni bir boyut kazanmıştır. Nitekim Derrida Platoncu gelenekteki yazı karşıtlı̆̆ının aksine metni sadece herhangi bir edebiyat ya da felsefe olarak ele almayıp genel olarak "hayat" anlamında kullanır. Derrida'ya göre metin ya da hayat kuralları bağlamsal değerlendirmelerden ibaret olduğu için zamanla değişmek durumundadır. ${ }^{53}$ Derridacı dekonstrüksiyonda, her metin tamamlanmamış bir söz olarak değerlendirilir. Différance bir "erteleme hareketi" dir. Zamansallığın tezahürü olarak farklılığın ertelenmesini içeren yaklaşım "anlam aralığı" sağlamakta ve böylece metne, metafizik gelenek içinde mümkün olmayan bir boyut kazandırmış olmaktadır. ${ }^{54}$ Söz konusu durumda Derrida'nın metni temel ilke kabul ettiğini ve buradan hareketle ona olayın bağlamı ve zamanın tekilliğini hesaba katarak farklı değerler yüklediğini ifade edebiliriz. Böylelikle Derrida temel ilkeye ya da köke bağlı kalarak esasında aynı ilke adına farklı zamanlarda farklı kararları alabilmenin imkânını gösterir. ${ }^{55}$ Nihai anlam ve mutlak fikrini yadsıyan bu yaklaşımın ahlaki hayata dair kesinlik ve mutlaklık iddialarını da yapısöküme uğrattı̆̆ını ifade edebiliriz. Söz konusu yapısökümünü sembolize eden différance kavramı ile Derrida, kesinlik ve mutlaklık iddialarının üstesinden gelmek için onlara referans olan ve belirli bir temeli esas alan özcü metafiziği

51 Martin Heidegger, Hümanizm Üzerine, 46-49.

52 Jacques Derrida, Gramatoloji, çev. İsmet Birkan (Ankara: Bilgesu Yayınları, 2014), 35-39.

53 Jacques Derrida, “Teoriyi İzlemek”, çev. Ebru K1lıç, Teoriden Sonra Hayat, ed. Michael Payne - John Schad (İstanbul: Agora Yayınları, 2004), 28-31

54 Stikkers, "Value as Ontological Difference", 137-154.

55 Banu Alan Sümer, “Jacques Derrida ve Etik”, Çağdaş Fransız Felsefesinde Etik, ed. Veli Urhan (Ankara: Hece Yayınlar1, 2006) 139-171. 
yadsır. ${ }^{56}$ Metafiziksel yapılara ait hakikat Derrida'nın différance analizlerine göre, anlamlandırmada asıl olan fark ve ayırımdır. Bu fark yasanın önceki bağlamından ayrılması ve kuralın zamanın ruhuna uygun biçimde yeniden icat edilmesi ${ }^{57}$ gibi değerlerin de yeniden yorumlanmasını gerektirir. Bu durumda sabit özler ve anlamlardan da bahsedilemez.

Mutlak ve kesin bir temellendirmenin söz konusu olduğu yapısalcı metafiziklerin aksine yapısöküm felsefesinde temellendirmeler başlangıcı olan kurucu merkezler yerine tarihsel bir strateji ve bağlam içerisinde zamansallıkta gerçekleşir. ${ }^{58}$ Varlık, akıl veya politik merkezleri yadsıyan bu yapı, sınırları belli, sabit ve süreklilik arz eden bir merkezden ziyade "sonsuz sayıda gösterme ikamelerinin oyuna girdiği bir yer-olmayan” bir örgütlenme biçimidir. Daha açık bir ifadeyle herhangi bir temel olmaksızın iyinin imkânını herhangi bir kural, bilgi, politik belirlenim ya da otoritede aramayan, bunun yerine görevin ve sorumluluk duygusunun ötesinde hesaplanamaz olan bir karar verilemezlik durumudur. ${ }^{59}$ Derrida'ya göre ahlak tam bu durumda kendini gösterir. Çünkü ona göre hazır kavramlar, kurallar ve şemalardan hareket ederek ortaya konulan davranışlar bir sorumluluk alma durumunu yansıtmaz. Ne yapılması gerektiğine dair kararsızlığın olduğu ve hazır hiçbir kuralın olmadığı yerde "kural icat etmek" gerekir. Kuralın olmadığı yerde icat, sorumluluk almak daha açık bir ifadeyle yeni değer üretmek anlamina gelir. ${ }^{60}$

Yukarıda ifade edildiği gibi değer üretmek; sorumluluk almaktır. Bu durum metne, yeni bir metinle cevap verecek biçimde oluşturulur. Nitekim yeni durumda, mevcudiyet metafiziğindeki kurucu temel ilke olarak var olan arkhe, telos, energeia, aletheia, mutlak, erdem ve kendinde iyi gibi bütün adlandırmalar yerini merkezî bir gösterilenin ve adlandırmaların olmadığı örgütlenmelere bırakır. Böylelikle iyide olduğu gibi merkeze alınan kurucu unsurdan hareketle çevre unsurların daha değersiz ve önemsiz kabul edilmesine dayalı belirlenimleri geçersiz kılınır. ${ }^{61}$ Ahlaki sorumluluk da önceden belirlenen iyi ile kötü arasında her türlü karşıtlıktan birini seçmekten ziyade kestirilemez tekil durumlar karşısında (olay) kişinin kendi yolunu bulma olanağının ifadesi olarak kabul edilir. Söz konusu durum iyinin aşkın bir amaç ya da nesnel bir ilişki yerine bir beklenti içermeyen "armağan hareketi” olarak okunmasını yansıtır. ${ }^{62}$

İyi ve kötüye dair yeni sorgulamalarla tikel durumlar karşısında bireye gerek kendi varoluşu ve gerekse öteki ile ilişkide geleneksel tutumdan farklı olarak yeni bir yol gösteren yapısöküm geleneği değerler alanında adeta merkezi olmayan mobil bir lokalizasyon teklif eder. Bu yeni merkezsizlik; merkez anlayışının mevcut bir Varlık

\footnotetext{
56 Küçükalp, Batı Metafiziğinin Dekonstrüksiyonu: Heidegger ve Derrida, 256-257.

57 Jacques Derrida, "Yasanın Gücü: Otoritenin Mistik Temeli”, çev. Zeynep Direk - Ece Göztepe, Şiddetin Eleştirisi Üzerine, haz. Aykut Çelebi (İstanbul: Metis Yayınları, 2010), 70-71.

Derrida, Gramatoloji, 107.

Derrida, "Yasanın Gücü: Otoritenin Mistik Temeli”, 74.

Derrida, “Teoriyi İzlemek”, 33.

61 Küçükalp, Batı Metafiziğinin Dekonstrüksiyonu: Heidegger ve Derrida, 340-341.

62 Alan Sümer, “Jacques Derrida ve Etik”, 139-171.
} 
biçiminden ziyade farklı değişkenlerin devreye girdiği bir fonksiyon olarak ${ }^{63}$ değerler alanının yeni karakterini temsil eder. Bu durum değerler alanını sabitlikler yerine yönelimler doğrultusunda kendiliğinden gerçekleşen bir yapı olarak öne çıkarır. Söz konusu durum, ahlaki hayata dair logos ya da din gibi belirleyici otoritelerin iktidarının reddedilmesi ${ }^{64}$ ve herhangi bir temel ve merkez olmaksızın değerlerin yeniden haklllaştırma ile her durum karşısında yeniden üretilmesinin imkânının gösterilmesi olarak da okunabilir.

\section{Sonuç}

Çalışmamızda iyi ve değer olarak farklı biçimde ele aldığımız ahlak anlayışları, farklı sistem ve referanslara göndermelerde bulunmaktadır. Geleneksel iyinin yerini almaya çalışan değerin esasında, modern dönemde iyinin yapısöküme uğratılmasının bir sonucu olduğunu görebiliriz. Bu anlamda Heidegger'in değer anlayışı da mevcudiyet metafiziği gereği Varlık ve var olanlar arasındaki ontolojik bir ayrıma dayalı iyi yerine, Varlığın insani deneyimle anlamlı ifşasını içeren iyiyi/değeri yansıtır. Mezkûr dönüşüm her şeyin kontrol edildiği bir Arşimet noktası ve metafizik temellendirme ile kendineyeterli ve kendiyle özdeş hiyerarşik bir düzeni içeren iyi karşısında fenomen ve referans ayrılığına dayalı temellendirmeyi yansıtan değerlere geçiş olarak da okunabilir.

Söz konusu geçiş, birbirine bağlı, Varlıksal, politik veya dinî nedenlerden dolayı önceden öngörülen sonuçlara matuf ve belirli kurucu kavramlar neticesinde tasarımlardan oluşan ahlaki iyiden tam bir kopuşu da yansitır. Teorik referans yerine fenomenolojik ifşa ile karakterize edilen ve zamansallıkta zeminlenen değerler, önceden öngörülen amaçlar yerine bağlamsallıkla ifade edilen ve daha çok tarihsel şartlarda şekillenen yapılar olarak tezahür eder. Geleneksel dönemin sabitelerinin aksine amaçların sürekli dinamik biçimde revize edildiği değerler alanının, taklit ve tekrar üzerinde kalıp çözümler üretmek yerine bireyin imkânları çerçevesinde ona rehberlik ettiğini söyleyebiliriz. $\mathrm{Bu}$ durumun sonucu olarak değerler alanında kurucu bir akıl ve harici bir otorite fikri içsel bir motivasyona dönüştürülür. Nitekim Heidegger'in yaklaşımında da bireyin sosyal ve psikolojik bütünlüğünün sağlanmasına ve kaygılarının giderilmesine yönelik olarak değerlerin açı̆̆a çıkması bireyin vicdanına seslenilerek, onu kurallarla hizaya getirmekten ziyade varoluşsal anlamda ona rehberlik ve tavsiye ile mümkün olur. Böylece, herhangi bir vekâlet söz konusu olmadan, bireyin kendi çabasıyla yaşamını bir dengede tutması ve güvenlik kaygılarını "dünya içinde" yatıştırması amaçlanır. Değerler alanındaki yaşama dair Heidegger 'de ki bu denge arayışının "ahlaki iyi"de olduğu gibi herhangi bir aidiyet, tarih üstü yargı ya da metafiziksel bir mutabakat yerine, bu-dünyada öteki ile ilişkide ve zamansallıkta açığa çıkan fenomenal hakikat ile temsil edildiğini de söyleyebiliriz.

Toparlayacak olursak geleneksel iyiden farklı olarak soyut bir insan ya da insanlık yerine somut tek bireyi esas alan ve insanı haricindeki her şeyden ayıran varoluşsal

\footnotetext{
63 Jacques Derrida, "Structure, Sign and Play in the Discourse of Human Science", çev. Alan Bass, Writing and Difference (London: Routledge, 2002), 352.

64 Niall Lucy, Derrida Sözlüğ̈̈, çev. Sabri Gürses (Ankara: Bilgesu Yayınları, 2012), 208.
} 
(existenz) belirlenimle temellenen değeri iyi yaşama dair farklı bir teklif olarak okumak da mümkündür. Heidegger'in var olanı "oluruna bırakma” olarak nitelendirdiği söz konusu yaşam, varoluşa gösterilen ihtimamla ve zamanın ruhuna uygun biçimde farklı anlamlara açılmaya imkân veren keşiflerin olduğu dinamik bir değerler yaşamıdır. Varlığın anlamından hareketle insanın anlam-değer dünyasının açılımını amaçlayan, günümüzde de etkileri fazlasıyla görülen söz konusu değer anlayışının bugünün çoğulcu dünyasında adeta yolculuk hâlinde olan insana kendi envanterini çıkarıp imkânlarını daha fazla kavrama olanağı sunduğu yadsınamaz. Fakat mevcudiyet metafiziği ve bundan mülhem ahlak eleştirisi üzerine neşvünema bulan değerlerin bugün gelinen noktada insanı hem teolojik hem de metafizik amaçlardan ve mutlak iyiden uzaklaştırdığı, buna karşında kamusal yaşam için gerekli kanonik yapıyı oluşturamadığı da malumdur. Bu nedenle insanlar arası karşılıklı ilişki ve fenomenal gerçeklikle kendiliğinden oluşan değerlerin dinî ve metafizik temellendirmelerle dolayımlanan nesnellik süreçlerine muhtaç olduğunu ifade etmemiz gerekmektedir.

\section{Kaynakça}

Alan Sümer, Banu. “Jacques Derrida ve Etik”. Çağdaş Fransız Felsefesinde Etik. ed. Veli Urhan. 139-171. Ankara: Hece Yayınları, 2006.

Barton, Perry. Ralph. General Theory of Value. Cambridge: Harvard University Press, 1950.

Çüçen, A. Kadir. Heidegger'de Varlıve Zaman. Bursa: Asa Yayınları, 3. Basım, 2003.

Derrida, Jacques. "Structure, Sign and Play in the Discourse of Human Science". çev. Alan Bass. Writing and Difference. 351-370. London: Routledge, 2002.

Derrida, Jacques. “Teoriyi İzlemek”. çev. Ebru Kılıç. Teoriden Sonra Hayat. ed. Michael Payne - John Schad. 1-52. İstanbul: Agora Yayınları, 2004.

Derrida, Jacques. “Yasanın Gücü: Otoritenin Mistik Temeli”. çev. Zeynep Direk - Ece Göztepe. Şiddetin Eleştirisi Üzerine. haz. Aykut Çelebi. 43-133. İstanbul: Metis Yayınları, 2010.

Derrida, Jacques. Gramatoloji. çev. İsmet Birkan. Ankara: Bilgesu Yayınları, 2. Basım, 2014.

Derrida, Jacques. Platon'un Eczanesi. çev. Zeynep Direk. İstanbul: Pinhan Yayınları, 2. Basım, 2014.

Dewey, John. "Theory of Valuation". International Encyclopedia of Unified Science, ed. Otto Neurath. Vol. II, No: 4. 1-62. Chicago: The University of Chicago, 2.Basım, 1943.

Foucault, Michel. Özne ve İktidar. çev. Işık Ergüden - Osman Akınhay. İstanbul: Ayrıntı Yayınları, 4 Basim, 2014.

Gülenç, Kurtul. “Bilim, Düşünme ve Varlık: Heidegger'de Fenomenolojik Hermeneutik”. Cogito Üç Aylk Düşünce Dergisi 64 (2010), 280-299.

Heidegger, Martin. Basic Questions of Philosophy. Trans. Richard Rojcewicz - Andre Schuwer. Bloomington \& Indianapolis: Indiana University Press, 1994.

Heidegger, Martin. Nedir Bu Felsefe? çev. Ali Irgat. İstanbul: Afa Yayınları, 1995.

Heidegger, Martin. "Metaphysics as History of Being". The End of Philosophy. Trans. Joan Stambaugh. 1-54. United States of America: University of Chicago Press, 2003.

Heidegger, Martin. Metafizik Nedir?. çev. Yusuf Örnek. Ankara: Türkiye Felsefe Kurumu, 3. Basım, 2009.

Heidegger, Martin. Varlk ve Zaman. çev. Kaan H. Ökten. İstanbul: Agora Kitaplığı, 2. Basım, 2011.

Heidegger, Martin. Sanat Eserinin Kökeni, çev. Fatih Tepebaşılı. Ankara: De Ki Basım Yayım, 2. Basım, 2011.

Heidegger, Martin. Hümanizm Üzerine, çev. Yusuf Örnek. Ankara: Türkiye Felsefe Kurumu, 2013. 
J. Ong, Walter. Sözlü ve Yazıll Kültürr: Sözün Teknolojileşmesi. çev. Sema Postacıŏlu Banon. İstanbul: Metis Yayınları, 5. Basım, 2010. https://doi.org/10.7827/turkishstudies.12319

Joas, Hans. The Genesis of Value as Genealog6y of Morality. çev. Gregory Moore. Chicago: The University of Chicago Press, 2000.

Johnson, Patricia Altenbernd. Heidegger Üzerine, çev. Adnan Esenyel Bursa: Sentez Yayınları, 2013.

Kenneth, W. Stikkers. "Value as Ontological Difference". Phenomenology of Values and Valuing. ed. James G. Hart - Lester Embree. 137-154. Dordrecht: Kluwer, 1996.

Kılıç, Emrullah. Metafiziksel İyi'den Değer'e: Ahlakın Yolculuğu. Ankara: Ankara Üniversitesi, Sosyal Bilimler Enstitüsü, Doktora Tezi, 2020.

Küçükalp, Derda. “Erdem Etiği”. Felsefe Ansiklopedisi. ed. Ahmet Cevizci. 5/628- 629. Ankara: Ebabil Yayınları, 2007.

Küçükalp, Kasım. Batı Metafiziğinin Dekonstrüksiyonu: Heidegger ve Derrida. Bursa: Sentez Yayınları, 2008.

Lawrence, McCarney Eugene. The Idea of Freedom in the Philosophy of William James. Chicago: Loyola University Chicago, The Faculty of Graduate School, Yüksek Lisans Tezi, 1963.

Lucy, Niall. Derrida Sözlüğü. çev. Sabri Gürses. Ankara: Bilgesu Yayınları, 2012.

Megill, Allan. Aşırılı̆̆ın Peygamberleri. çev. Tuncay Birkan. Ankara: Ayraç Kitabevi, 2.Basım, 2008.

Nenon, Thomas. "Values, Reasons for Actions, and Reflexivity”. Phenomenology of Values and Valuing. ed. James G. Hart - Lester Embree. 28/131-134. Dordrecht: Kluwer, 1996. https://doi.org/10. /978-94-017-2608-5_8

Nietzsche Friedrich. Güç İstenci. çev. Nilüfer Epçeli. İstanbul: Say Yayınları, 2. Basım, 2014.

Nietzsche, Friedrich. Putların Alacakaranlığı. çev. İsmet Zeki Eyüboğlu İstanbul: Say Yayınları, 5. Basim, 2014.

Otteson, James. “Adam Smith's Marketplace of Morals”. Archiv für Geschichte der Philosophie 84/2 (2002), 190-211. https://doi.org/10.1515/agph.2002.009

Platon. Phaidros. çev. Furkan Akderin. İstanbul: Say Yayınları, 2017.

Rorty, Richard. Felsefe ve Doğanın Aynası. çev. Funda Günsoy Kaya. İstanbul: Paradigma Yayınları, 2006.

Steiner, Georg. Heidegger. çev. Süleyman Kalkan. Konya: Vadi Yayınları, 1996.

Tatar, Burhanettin. “Ahlakın Kaynağı Sorunu”. Ahlak Felsefesi Yazıları. ed. Lokman Çilingir. 11-33. Ankara: Elis Yayınları, 1. Basım, 2015.

Tatar, Burhanettin. Din, İlim ve Sanatta Hermenötik. İstanbul: İSAM Yayınları, 2014. https://doi.org/ 10.14395/jdiv371

Türer, Celal. "Modernliğin Yöntem Tiranlığı”. Eskiyeni / 17 (Haziran 2010), 5-10.

Türer, Celal. Ahlaktan Felsefeye Felsefeden Ahlaka. İstanbul: Dergâh Yayınları, 2017.

Urhan, Veli. Michel Foucault ve Düşünce Sistemleri Tarihi. İstanbul: Say Yayınları, 2013.

Wiggins, David. Needs, Values, Truth. ABD: Oxford University Press, 1998. 